\title{
DISCLOSURES AND PERCEPTIONS OF PRACTITIONERS ON ITEMS OF FINANCIAL AND SOCIAL REPORTING INDEX DEVELOPED FOR MALAYSIAN ISLAMIC BANKS
}

\author{
Asri Marsidi* \\ Universiti Malaysia Sarawak \\ Hairul Azlan Annuar \\ Universiti Islam Antarabangsa Malaysia \\ Abdul Rahim Abdul Rahman \\ Universiti Sains Islam Malaysia
}

\begin{abstract}
The study examines the views of accountants concerning the importance of items in the developed index for Islamic Financial and Social Reporting (IFSR) as well as measures and discusses the level of weighted IFSR for Islamic banks based on the IFSR index developed for Malaysian Islamic banks. The research uses the questionnaires and the annual reports to collect the relevant data with respect to the views of accountants and IFSR score of Islamic banks respectively. The findings suggest that the financial part, and the auditing and governance part in the index of IFSR are important and close to important, respectively, while the social part is viewed as fairly important. Moreover, the other finding reflects that the weighted IFSR for Islamic banks in Malaysia is considered as fair. The findings with respect to the level of weighted IFSR disclosure may not be generalised to the years prior and after the examination period. The research provides empirical insights on the importance of items in the IFSR index and the weighted level of IFSR practices among Malaysian Islamic banks. The paper highlights the importance of items in the IFSR index as well as IFSR disclosure in enhancing the accountability and sustainability of Islamic banks.
\end{abstract}

Keywords: Disclosures; Practitioners' Perceptions on IFSR Index; Accountability; Stakeholders Theory; Legitimacy Theory; Islamic Banks.

\section{INTRODUCTION}

Islamic finance has been regarded as part of an Islamic economic system that has inherent social relations (Ahmed, 2011). In this regard, Islamic banks have been established since 1970s with the aim of upholding socio economic justice as promulgated by Islamic teachings. Consequently, all Islamic bank products or services have to be offered or delivered within the parameters of Shari'ah which mean that they are not allowed to engage in any kind of interest ( $r i b a$ ) bearing borrowing or lending contracts (Archer \& Karim, 2007).

To date, the formation of Islamic banks is believed to have captured the majority of Muslim customers worldwide, which is approximately more than 1.3 billion or around $24 \%$ of the world's population. The overwhelming acceptance of Islamic bank products or services could be due to the fact that the Islamic banking and finance industry is on its way to becoming a truly viable and competitive alternative to the

-Corresponding Author: Faculty of Economics and Business, Universiti Malaysia Sarawak, 94300 Kota Samarahan, Sarawak, Malaysia. Tel: +6082 584389 Email: maasri@unimas.my 
conventional system, and, in recent times, has made a series of breakthroughs and improvements (Khan \& Bhatti, 2008).

In the Malaysian scenario, in 1983, Bank Islam Malaysia Berhad (BIMB) became the first Islamic bank to be established. The bank has now proven its capability to succeed as they currently have more than 80 branches throughout Malaysia. According to the Central Bank of Malaysia, Bank Negara Malaysia (BNM) (2017), there are 16 banks operate as either fully fledged or subsidiary Islamic banks in Malaysia.

Nonetheless, the issue of accountability is of immense concern in today's business world, as demonstrated by the demise of huge and well established corporations around the world in recent years. Parmalat, Enron and WorldCom are a few examples of such classical collapses in the history of corporations. On the local front, accounting irregularities have been found to exist in companies like Transmile, Energo, Welli Multi, Megan Media and GP Ocean (Securities Commission of Malaysia, 2010).

Many corporate failures have been linked to the quality of corporate financial statements. The corporate demise and scandals, which are normally caused by accounting irregularities, are a sign of poor credibility, integrity and independence. As a result, this has severely diminished the status or standing of the accounting profession in the eyes of the public, who have begun to openly criticize how accountants perform their professional duties in providing a true and fair view of the corporate financial position.

The concept for the Islamic financial and social reporting (IFSR) generally lies in the blend of reporting requirements from the Islamic financial and social perspectives (Marsidi et al., 2016). The existing Islamic social reporting (ISR) concept includes financial components within its reporting system concept but it is not as comprehensive as the social components. Hence, the IFSR has been developed to give more emphasis to the financial aspects while retaining the core components of social reporting.

The Islamic financial components in the IFSR are designed based on the technical approach from the setters of the relevant existing standards and guidelines, i.e. MASB, AAOIFI, IFSB and BNM. In contrast, the ISR concept has essentially arisen from the theoretical perspective. As such, the technical and theoretical methods that are used in the IFSR will broaden and deepen the implications of IFSR within its context of usage.

Considering the growing importance of the Islamic banking industry, particularly in Malaysia, and the alarming issue of accountability in the world of business today, the study has several objectives. The first objective of the paper is to examine the views of the practitioners, i.e. accountants, concerning the importance of the components or items in the IFSR index developed by Marsidi et al. (2016). The other objective of the paper is to examine the extent of compliance or awareness among the Islamic banks in Malaysia with respect to the IFSR.

The study is expected to contribute towards enhancing the accountability and sustainability of Islamic banks. The paper comprises ten sections including the introduction and limitation and suggestions for future research. The next sections present the discussions on accountability, transparency and social reporting as well as the stakeholder theory. Thereafter, the paper discusses the legitimacy theory. In the subsequent sections, the study discusses the IFSR, methodology of study, breakdown of respondents, views concerning the importance of items in the IFSR index, the weighted score for IFSR and the 
discussion about the weighted score for IFSR for Islamic banks in Malaysia and conclusion. The paper ends with the limitations and suggestions for future research.

\section{ACCOUNTABILITY, TRANSPARENCY AND SOCIAL REPORTING}

Gray et al. (1996) used the principle-agent contract model to define the concept of accountability as, "when someone is held responsible for actions, he has the duty to provide an account but not necessarily a financial account or reckoning of those actions". Through this definition, the principal (accountee) grants power and authority to the agent (accountor) to manage the resources. Once the principal and agent have entered into the contractual relationship, the agent will have to fulfil the objectives and to account all his actions to the principle.

Nevertheless, Roberts and Scapens (1985) offer a broader definition of accountability as to give and demand reasons for any conduct. In their framework of accountability, the focus is on the accounting practice that uses the system of accountability concept in referring to the accounting system. Accounting information in hierarchical forms of accountability provides an avenue to define the significant of accounting events. Roberts (1991) argues that the conventional accounting effect lead to an individualizing form of accountability under the hierarchical forms of accountability. This has resulted in a situation where a lonely sense of self is being surrounded by the perception of others.

The development of corporate accountability to date has seen a significant change in terms of to whom corporate managers are accountable to and accountable for. According to Porter (2009), such extension is due to the change in society's norms over the time. Such a change is also because of the growth of business enterprises has extended their power and affects the society as well. Thus, in turn, will affect the extent of accountability required from the corporate managers.

On the other hand, the Islamic accountability states that Muslims will be accounted for whatever they do in this world and in the hereafter. Hence, Muslims have to fulfil the will of Allah in order to seek his pleasure (rida') and the promised rewards in the hereafter. The importance of accountability to man's life also has been manifested through the prophet of Islam as, "Each one of you is a guardian and each guardian is accountable to everything under his care".

The concept of transparency entails that corporations are responsible to a wide spectrum of stakeholders. Its aim should not focus strictly on monetary values but also on social responsibility to the ummah. Therefore, corporations should also disclose information regarding its policy, activities undertaken, contribution to the community, and the use of resources and protection of environment (Haniffa, 2002).

Further, the concept of accountability as positioned by Islam (either in business or in other aspects of life) is based on the religious belief of tawhid that requires total commitment to the will of God and involves both submission and a mission to follow the Shari'ah in all aspects of life (Baydoun \& Willet, 2000). In order to serve the objective of social accountability, a principle of full disclosure of accounting information is needed (Baydoun \& Willet, 2000). However, full disclosure here does not mean that all information should be reported but rather the disclosure of any information that should be rightfully given to members of the community in accordance with the principles of the Shari'ah. Islamic disclosure practices should, like Islamic law, not be based upon practicality but on a moral sense.

In short, companies' disclosure policies need to change because the values, norms, beliefs and attitudes of individuals in society are always changing and there is no consistency in what will be demanded from 
companies by society from one period to the next (Haniffa, 2002). The nature of what is considered to be responsibility is constantly changing and developing; moral and natural rights in a society exist but changing and developing over the time (Tinker, 1991). However, simply because it is difficult to establish such rights, responsibilities, and accountability with certainty does not mean that these things do not exist or can be ignored.

\section{STAKEHOLDER THEORY}

The term stakeholder is defined by Freeman (1984: 46) as “....any group or individual who can affect or is affected by the achievement of an organization's objectives...". Hence, as noted by Simmons (2004), the stakeholder theory offers organizations an avenue to identify and bring together the diverse interests of stakeholders. This is achieved through the recognition of organizational obligations to broader and more ethically concerned constituencies.

The stakeholder theory generally argues that all stakeholders have a right to participate in the corporate decisions that affect them. The theory also mentions that managers have a fiduciary duty to protect and serve the interests of all stakeholder groups. As asserted by Wearing (2005), the stakeholder theory emphasizes the importance of entire parties that could be affected by corporate operations and activities.

In addition, the stakeholder theory states that the objective of the firm ought to be the promotion of the interests of all the related parties and not only the shareholders. This is because, as argued by Graves et al., (2001), every party has different stake or function on corporations. Therefore, the stakeholder theory actually concerns the managerial conception about the strategy and ethical value of organizations. In this respect, the stakeholder theory can also be described or elaborated through management and ethical branches (Deegan, 2013).

The proposed IFSR by Marsidi et al. (2016) is perceived as an avenue that can be used by organizations or corporations, such as Islamic banks, to create a rapport and develop confidence with their stakeholders. This is because the items of disclosure, as required under IFSR, require information concerning the financial and social needs of not only the owner or shareholders but also the other stakeholders.

\section{LEGITIMACY THEORY}

The legitimacy theory views corporations as having no right to be present and operate if their values are not being regarded as consistent with the values of the society at large (Magness, 2006; Dowling \& Pfeffer, 1975). In light of this, the legitimacy theory depends upon the insight that a social contract is exist between the companies and the society where they operate (Deegan \& Unerman, 2011).

A social contract is generally a numerous of expectations of the society in relation to how corporations should carry out their operations (Deegan, 2002). In this context, corporations need to act or conduct their business operations and activities within the expectations framework or socially identified responsible behaviour of the society in order to be accepted and therefore continue to exist and operate successfully (O'Donovan, 2002). From this point of view, the legitimacy theory stresses that corporations must be seen as considering the rights of the society at large in addition to their investors. 
Nonetheless, Newson and Deegan (2002) argue that the legitimacy itself can also be threatened although the corporate performance is consistent with the society expectation of performance since it is viewed to be affected by the disclosure of information and not by the undisclosed information on the changes of action made by the companies. According to Magness (2006), the legitimacy theory is used in accounting studies because the theory helps to explain about the items addressed or highlighted by managements of corporations with respect to their communication with outsiders.

In this perspective, considering the legitimacy theory is basically relied upon the society's views, corporate managements are hence required to provide relevant information in order to change the perceptions of outside users with regard to their corporations (Cormier \& Gordon, 2001). Lightstone and Driscoll (2008) argue that, from this respect, both mandatory (i.e. regulation - financial statements) and voluntary disclosures (i.e. information provided in other sections of the annual report) are viewed as able to lead to legitimation.

The disclosure with respect to corporate social responsibility is argued to have an essential impact in enhancing not only corporate reputation but also to mirror a better social and environmental conduct (Branco \& Rodrigues, 2008). Moreover, a good level of corporate social responsibility disclosures is strongly linked to the reputation of companies in the case of stakeholder group or stakeholder approach (Bayoud et al., 2012).

From the Islamic perspective, the social responsibility and accountability lie upon the framework that is derived from the Qur'an and Sunnah of the Prophet Muhammad (Pbuh). As such, the anticipations of Islamic believers from Islamic based organizations or corporations are unequivocal (Farook et al., 2011). On the other hand, the disclosure with regard to relevant social information by the Islamic banks is perceived as not only to discharge their responsibility but also to earn legitimacy in order to remain exists in the society (Maali et al., 2006; Haniffa, 2002).

\section{ISLAMIC FINANCIAL AND SOCIAL REPORTING (IFSR)}

Financial reporting from an Islamic perspective concerns the accountability of the corporate management towards all corporate stakeholders. The key agenda is to provide all relevant and related parties with the necessary financial information that can assist them to achieve their objectives.

The MASB Technical Release $i-3$ is considered to be essential since it covers the presentation of financial statements by IFIs in the Malaysian context. The Guidelines on Financial Reporting for Licensed Islamic Banks (GP8-i) is another reporting requirement for Islamic banks in Malaysia issued by BNM to provide the basis for presentation and disclosure of financial statements and reports for Islamic banks.

Meanwhile, AAOIFI was established within the last two decades to enhance the confidence of users of the financial statements of Islamic financial institutions about the information that is produced by these institutions. Besides, IFSB is regarded as one of the main supervisory bodies in addition to the SSB within the milieu of Islamic finance (Alexakis \& Tsikouras, 2009) through the issuance of guiding principles on corporate governance for institutions offering only Islamic financial services in 2006.

According to Haniffa (2002), there are two objectives of ISR, namely, (i) to demonstrate accountability to God and the community, and (ii) to enhance the transparency of business activities by providing relevant information in conformance with the spiritual needs of Muslim decision-makers. Hence, the 
ISR relies on social relations that need to be captured through accountability, social justice and ownership (Maali et al., 2006).

In Islam, the concept of tawhid presents a dissimilar and wider concept of accountability than the one implied in the conventional world (Baydoun \& Willet, 2000). This notion becomes the basis for Islamic social justice in which Islam outlines the economic growth that leads to a more impartial allotment of power and prosperity (Sulaiman \& Willet, 2001).

The concept of ownership is also central to the concept of accountability in Islam as Muslims believe that they are only the trustees for the wealth they possess (Lewis, 2006), and, thus, they will be accountable to Allah in the hereafter for all their deeds in this world, as stated in the Quran (2:284):

To Allah belongeth all that is in heavens and on earth. Whether ye show what is in your minds or conceal it, Allah calleth you to account for it.

Moreover, as noted by Farook et al. (2011), Aribi and Gao (2010) Hassan and Harahap (2010) as well as Haniffa and Hudaib (2007), the concept of ultimate accountability to Allah in which humans are viewed as Khalifah (vicegerent) is an important concept in corporate social reporting from an Islamic perspective since humans are expected to protect the earth and its creatures within it as entrusted upon them.

Besides, in the context of corporations i.e. Islamic banks, the concept of accountability is seen as the relationship between corporations and groups of people, with Allah (Othman \& Md. Thani, 2010). In this regard, as asserted by Maali et al. (2006), this concept can be perceived as an extension of the concept of tawhid which is basically referred to as the unity with Allah.

In terms of disclosure, the Islamic corporate responsibility report can be classified according to five themes: (a) finance and investment, (b) product, (c) employees, (d) community, and (e) the environment (Haniffa, 2002). Although the categories look similar to the conventional social reporting practices the differences can be observed through the type and emphasis of the information disclosed, as they are grounded within the Islamic ethical principles.

\section{METHODOLOGY OF THE STUDY}

The IFSR index ${ }^{1}$ as presented in Table 1 below is developed based on the relevant requirements of MASB (Tri-3), AAOIFI, IFSB and BNM (GP8-i) and the relevant contents of ISR developed and proposed by Maali et al. (2006) and Haniffa (2002) (Marsidi et al., 2016).

In order to seek the views of the accountants about the level of importance of the index of IFSR, the study developed and distributed a survey to the accountants and/or practitioners who are directly involved in the financial reporting requirement of Islamic banks. The IFSR index is divided into three parts, namely, Part A: Finance, Accounting and Investment (Financial), Part B: Employee, Society and Environment (Social) and Part C: Auditing and Governance (Governance). Part A consists of 20 index items whereas Part B encompasses 10 index items, and Part C has 8 index items. In total, there are 38 items in the IFSR index.

\footnotetext{
${ }^{1}$ The IFSR index excludes studies by Farook et al. (2011), Aribi and Gao (2010), Othman and Md. Thani (2010), Hassan and Harahap (2010) as well as Haniffa and Hudaib (2007) because the index is developed prior to the examination of annual reports of 2007.
} 
Table 1: Index of IFSR

\begin{tabular}{|c|c|c|}
\hline No. & Items of reporting & "Basis of Reference \\
\hline \multirow{9}{*}{1.} & Finance, accounting and investment & \\
\hline & Reports shall comprise the following: & GP8-i BNM \\
\hline & i. Performance overview; & \\
\hline & ii. Statement of corporate governance; & \\
\hline & iii. Directors' report; & \\
\hline & iv. Statement by directors; & \\
\hline & $\begin{array}{l}\text { v. Statutory declaration by director or person responsible for } \\
\text { preparation of financial statements of Islamic banks; }\end{array}$ & \\
\hline & vi. Auditor's report; and & \\
\hline & vii. Shari'ah committee's report. & \\
\hline \multirow[t]{6}{*}{2.} & Financial statement shall comprise the following: & GP8-i BNM \\
\hline & i. Balance sheet; & \\
\hline & ii. Income statement; & \\
\hline & $\begin{array}{l}\text { iii. Statement of changes in equity showing either all changes in } \\
\text { equity or changes in equity other than those arising from } \\
\text { capital transactions with owners and distributions to owners; }\end{array}$ & \\
\hline & iv. Cash flow statement; and & \\
\hline & v. Accounting policies and explanatory notes. & \\
\hline 3. & $\begin{array}{l}\text { Statement of financial position of an IFI shall disclose the following: } \\
\text { i. Assets; } \\
\text { ii. Liabilities; and } \\
\text { iii. Equity. }\end{array}$ & Tri-3 MASB; GP8-i BNM \\
\hline 4. & Separate reporting on IFI's assets, liabilities and equity in the notes. & Tri-3 MASB; GP8-i BNM \\
\hline 5. & $\begin{array}{l}\text { Income analysis is reported based on types of investment and } \\
\text { financing of customers. }\end{array}$ & Tri-3 MASB; GP8-i BNM \\
\hline \multirow[t]{4}{*}{6.} & Presentation of dividends recognised: & Tri-3 MASB; GP8-i BNM \\
\hline & $\begin{array}{l}\text { i. Disclosed either in statement of changes in equity or in the } \\
\text { notes; }\end{array}$ & \\
\hline & ii. Amount distributed to owners during the period; and & \\
\hline & iii. Related amount per share. & \\
\hline \multirow[t]{4}{*}{7.} & Zakat obligations: & \\
\hline & i. Method; & Maali et al. (2006); GP8-i BNM \\
\hline & ii. Amount and beneficiaries; and & Haniffa (2002); GP8-i BNM \\
\hline & iii. Payment on behalf of depositors, shareholders and others. & Tri-3 MASB; GP8-i BNM \\
\hline 8. & Policy on late repayments and insolvent clients/bad debt written off. & Maali et al. (2006) \\
\hline \multirow[t]{7}{*}{9.} & Disclosure of non-allowable earnings or expenditure prohibited by & \\
\hline & Shari'ah: & \\
\hline & i. Amount of earnings realised; & Tri-3 MASB; Haniffa (2002) \\
\hline & ii. Nature of earnings realised; & Tri-3 MASB; Haniffa (2002) \\
\hline & iii. Amount of expenses; & Haniffa (2002); Tri-3 MASB \\
\hline & iv. Nature of expenses; and & Haniffa (2002); Tri-3 MASB \\
\hline & v. Disposal manner of non-halal income. & Tri-3 MASB \\
\hline \multirow[t]{2}{*}{10.} & Product or service reporting & AAOIFI \\
\hline & i. Activities and $\%$ of profit contribution & Haniffa (2002) \\
\hline \multirow[t]{6}{*}{11.} & Reporting on significant concentrations of asset risks in the & Tri-3 MASB \\
\hline & following areas: & \\
\hline & i. Geographical areas; & \\
\hline & ii. Customer groups; & \\
\hline & iii. Industry sectors; or & \\
\hline & iv. Other concentrations of risk that are appropriate. & \\
\hline
\end{tabular}


Table 1: Index of IFSR (cont.)

\begin{tabular}{cc}
\hline \hline No. & \multicolumn{1}{c}{ Items of reporting } \\
\hline 12. & Bases of profit allocation between owners' equity and investment \\
account holders (IAHs) (Please refer to the note for description on \\
IAHs). \\
13. Reporting of concentration of sources of investment accounts and \\
their equivalent and other accounts. \\
14. Disclosure of investment accounts distribution and their equivalent \\
and other accounts in accordance with respective periods to maturity. \\
15. Reporting on distribution of assets in accordance with respective \\
periods to maturity or expected periods to cash conversion. \\
16. Disclosure of commitment and contingencies: \\
i. Nature of commitments that are irrecoverable; \\
ii. Amount of commitments that are irrecoverable; \\
iii. Nature of contingencies arising from direct credit substitutes, \\
transaction related contingencies, sales and repurchase \\
agreements, and other contingencies of a similar nature; and \\
iv. Amount of contingencies arising from direct credit substitutes, \\
transaction related contingencies, sales and repurchase \\
agreements, and other contingencies of a similar nature.
\end{tabular}

17. Reporting of co-mingling various types of deposit into a single funding pool:

i. Method of income allocation among various categories of deposit.

18. Disclosure of profit distribution derived from investment of depositors' funds at the gross level:

i. After deducting expenditure to the extent that they are directly attributable to the investment of those funds.

19. Reporting of specific investment accounts:

i. Separate disclosure of profits or losses; and

ii. Not to be offset with profits or losses from other items.

20. Adequate and timely disclosure:

i. Information on investment accounts:

a. Method of calculation of profits;

b. Asset allocation;

c. Investment strategies; and

d. Mechanics of smoothing any returns.

ii. Information on any related party transactions and treatment of material events.

\title{
Employees, society and environment
}

21. Education and training / Human capital development.

22. Recruitment policy.

Tri-3 MASB; GP8-i BNM

Tri-3 MASB

Tri-3 MASB; GP8-i BNM

Tri-3 MASB; GP8-i BNM

AAOIFI

\author{
Tri-3 MASB; GP8-i BNM
}

Tri-3 MASB; GP8-i BNM

Tri-3 MASB; GP8-i BNM

IFSB

23. Remuneration policy.

24. Career advancement policy.

25. Retirement policy.

26. Charities / gifts.

27. Social activities.

28. Policy on social issues.

29. Policy on environmental issues.

30. Saddaqa / donation.

Maali et al. (2006);

Haniffa (2002)

Marsidi et al. (2016)

Marsidi et al. (2016)

Marsidi et al. (2016)

Marsidi et al. (2016)

Maali et al. (2006)

Maali et al. (2006)

Marsidi et al. (2016)

Marsidi et al. (2016)

Haniffa (2002) 
Table 1: Index of IFSR (cont.)

\begin{tabular}{|c|c|c|}
\hline No. & Items of reporting & Basis of Reference \\
\hline \multirow{5}{*}{31.} & Auditing and governance & \\
\hline & $\begin{array}{l}\text { Statement of corporate governance should include the following: } \\
\text { i. Board responsibility and oversight: }\end{array}$ & GP8-i BNM \\
\hline & ii. Internal audit and internal control activities; & \\
\hline & iii. Risk management; and & \\
\hline & iv. Management reports. & \\
\hline \multirow[t]{4}{*}{32.} & Existence of comprehensive governance policy framework that sets & \\
\hline & out: & \\
\hline & $\begin{array}{l}\text { i. Strategic roles and functions of each organ of governance and } \\
\text { the mechanisms of balancing their accountabilities to various } \\
\text { stakeholders; and }\end{array}$ & IFSB \\
\hline & $\begin{array}{l}\text { ii. Roles and authority of Shari'ah advisor or Shari'ah board in } \\
\text { monitoring the IFI's activities pertaining to Shari'ah matters. }\end{array}$ & Tri-3 MASB; GP8-i BNM \\
\hline 33. & $\begin{array}{l}\text { Investment account holders' (IAHs) rights to monitor investment } \\
\text { performance, i.e. disclosure of policies and practices in respect of the } \\
\text { investment accounts offered. }\end{array}$ & IFSB \\
\hline 34. & $\begin{array}{l}\text { Disclosure of practices, procedures and entitlements that adequately } \\
\text { address any undesirable ambiguity that are tantamount to gharar } \\
\text { with respect to the profit equalization reserve (PER). }\end{array}$ & IFSB \\
\hline 35. & Disclosure of an appropriate mechanism for obtaining rulings from & IFSB \\
\hline & $\begin{array}{l}\text { Shari'ah scholars, applying fatawa and monitoring Shari'ah } \\
\text { compliance. }\end{array}$ & \\
\hline 36. & $\begin{array}{l}\text { Information on compliance with the Shari'ah rules and principles as } \\
\text { expressed in the rulings of the Shari'ah scholars. }\end{array}$ & IFSB \\
\hline 37. & $\begin{array}{l}\text { Reporting of rulings of the Shari'ah scholars that are used to examine } \\
\text { compliance with Shari'ah rules and principles. }\end{array}$ & IFSB \\
\hline 38. & Policy of treatment for non-compliant activities. & Marsidi et al. (2016) \\
\hline
\end{tabular}

Source: Marsidi et al. (2016)

In the survey, the respondents were required to assign the weight ranging from 1-5 for each of the items in the developed and presented IFSR index. Number 1 represents strongly not important whereas number 5 denotes strongly important. The remaining numbers, 2, 3 and 4, represent not important, fairly important and important, respectively. The questionnaires were sent to all 16 Islamic banks that operate either as fully fledged Islamic banks or Islamic subsidiaries in Malaysia.

The questionnaires were also sent to Bank Kerjasama Malaysia Bhd (Bank Rakyat), Bank Pertanian Malaysia Bhd (Agrobank) and Bank Perusahaan Kecil \& Sederhana Malaysia Bhd (SME Bank) in consideration of their involvement in providing Islamic banking products and services. Each bank was provided with five copies of the questionnaire. The weighted score of IFSR was based on the disclosure of the 12 Islamic banks in Malaysia for four consecutive years, from 2007 to 2010. The 12 banks were selected because they had all the annual reports for the period of examination.

There were 42 completed questionnaires from 12 Islamic banks returned in the survey. These figures reflect a response rate of $44.2 \%$ (42 out of 95) out of the total questionnaires sent, and 63.2\% (12 out of 19) out of the total Islamic banks involved in the survey. The breakdown of the respondents is presented in Table 2 below. 
Table 2: Breakdown of Respondents

\begin{tabular}{cccc}
\hline \hline No. & Islamic Banks & No. of Respondents & Percentage (\%) \\
\hline 1. & Affin Islamic Bank Bhd & 5 & 11.9 \\
2. & Asian Finance Bank Bhd & 3 & 7.1 \\
3. & Maybank Islamic Bhd & 5 & 11.9 \\
4. & CIMB Islamic Bhd & 5 & 11.9 \\
5. & OCBC Al-Amin Bhd & 2 & 4.8 \\
6. & Hong Leong Islamic Bank Bhd & 1 & 2.4 \\
7. & SME Bank & 1 & 2.4 \\
8. & Public Islamic Bank Bhd & 4 & 9.5 \\
9. & Al-Rajhi Bank (M) Bhd & 5 & 11.9 \\
10. & Kuwait Finance House (M) Bhd & 5 & 11.9 \\
11. & Bank Kerjasama Malaysia Bhd (Bank Rakyat) & 5 & 11.9 \\
12. & Bank Muamalat Malaysia Bhd & 1 & 2.4 \\
\hline \multicolumn{4}{c}{ Total }
\end{tabular}

\section{VIEWS CONCERNING THE IMPORTANCE OF ITEMS IN THE IFSR INDEX}

For items in Part A (Finance): Finance, Accounting and Investment, the minimum mean reported is 3.64 whereas the maximum is recorded at 4.98 . The overall mean is reported at 4.11. This shows that, generally, the respondents view this part as important. With respect to Part B (Social): Society, Employee and Environment, the Table demonstrates that the respondents treat this section as fairly important, as shown by the overall mean of 3.35. In this part, the highest mean reported is 3.71 while the lowest mean recorded is 3.17 .

For the last part of the index, i.e. Part C (Governance): Auditing and Governance, the statistics, as displayed in the Table, indicate that the respondents are of the opinion that the section is fairly important in the index of IFSR. In addition, as shown by the very close overall mean to 4, i.e. 3.96, this reflects that some of the respondents think that this section is important. The minimum and maximum mean are 3.67 and 4.52 , respectively.

Table 3: Mean of the Views on the Index of IFSR

\begin{tabular}{cccc}
\hline \hline Mean & Part A: Financial & Part B: Social & Part C: Governance \\
\hline Minimum & 3.64 & 3.17 & 3.67 \\
Maximum & 4.98 & 3.71 & 4.52 \\
Overall & 4.11 & 3.35 & 3.96 \\
\hline \hline
\end{tabular}

Overall, i.e. for all the three parts, the minimum mean recorded is 3.17 , whereas the maximum mean reported is 4.98. The results from these three parts demonstrate that the respondents endorse the importance of the financial part. Although the overall result for the auditing and governance part is slightly lower than for the financial part, it is very close to being regarded as important as well. The results also suggest the need for social disclosure among the Islamic banks in Malaysia.

\section{DISCUSSION ON THE WEIGHTED SCORE OF IFSR}

Forty-eight annual reports were used and examined in this study. The 12 Islamic banks involved are as presented in Table 4 below. 
Table 4: List of Islamic Banks involved in the Study

\begin{tabular}{ccc}
\hline \hline No. & Islamic Banks & $\begin{array}{c}\text { No. of Annual Reports } \\
(\mathbf{2 0 0 7 - 2 0 1 0})\end{array}$ \\
\hline 1. & Affin Islamic Bank Bhd & 4 \\
2. & Al Rajhi Banking \& Investment Corporation (Malaysia) Bhd & 4 \\
3. & AmIslamic Bank Bhd & 4 \\
4. & Asian Finance Bank Bhd & 4 \\
5. & Bank Islam Malaysia Bhd & 4 \\
6. & Bank Muamalat Malaysia Bhd & 4 \\
7. & CIMB Islamic Bank Bhd & 4 \\
8. & EONCAP Islamic Bank Bhd & 4 \\
9. & Hong Leong Islamic Bank Bhd & 4 \\
10. & Kuwait Finance House (M) Bhd & 4 \\
11. & RHB Islamic Bank Bhd & 4 \\
12. & Bank Kerjasama Rakyat Malaysia Bhd & 4 \\
\hline \multicolumn{2}{c}{ Total } & $\mathbf{4 8}$ \\
\hline \hline
\end{tabular}

For the purpose of discussion concerning the weighted IFSR score, the total score is rated based on the rating, as presented in Table 5 below. The rating is developed after considering among others the level of preparedness of the Islamic banks. In this regard, many of the Islamic banks are still new in the industry except the two full-fledged Islamic banks i.e. BIMB and BMMB. Thus, the focus of these new Islamic banks are mainly still on the performance issues rather than the disclosure.

As noted by Abatecola (2012) through their studies, only $33.33 \%$ of the newborn businesses survived during the first 3 years after the enterprises established. This is consistent with the concept of liability of newness by Stinchcombe (1965) that asserts the failure rates of businesses are much higher in the early years of operations although decline over the time.

Table 5: Rating of Score

\begin{tabular}{cc}
\hline \hline Score (\%) & Rating \\
\hline 70 and Above & Very Good \\
$60-69$ & Good \\
$50-59$ & Fair \\
$40-49$ & Poor \\
39 and Below & Very Poor \\
\hline \hline
\end{tabular}

The mean for the total weighted score reflects that the level of disclosure with respect to IFSR for Islamic banks in Malaysia is fair since the mean scores are between 52\% and 57\% from 2007 to 2010. In terms of the scores for the individual part, the mean scores for the financial as well as auditing and governance portray that their levels of disclosure are very good and good, respectively. However, the mean scores for the social part are considered to be quite alarming since the scores are very poor. The rating of the weighted scores is provided in Table 6 below.

Table 6: Rating of the Weighted Scores

\begin{tabular}{ccc}
\hline \hline Parts & Mean of \% Score & Rating \\
\hline Financial & 73 & Very Good \\
Social & 17 & Very Poor \\
Auditing and Governance & 60 & Good \\
Total & 55 & Fair \\
\hline \hline
\end{tabular}


The results indicate that the overall weighted score is largely inclined towards the financial as well as the auditing and governance scores. Hence, in principle, Islamic banks have no problem in complying with the requirements as outlined by the respected regulatory bodies, particularly concerning the financial aspects, i.e. mean score of $73 \%$. Nevertheless, there are a few areas that need to be highlighted in the financial, social as well as auditing and governance parts.

\subsection{Financial}

Among the areas of concern in the financial part is zakat. Zakat is one of the pillars in Islam, which aims to assist the needy. Literally, zakat refers to the purification of one's assets and income. In this respect, zakat is also considered as the act of worship (Aribi \& Gao, 2012). It is significant to pay zakat because zakat is one of the clear examples of emphasis promulgated by Islam on social justice (Maali et al., 2006). According to An-Nabhani (1997), zakat is a must pay fund made to the treasury regardless of whether there is a need for such payment or not.

From this perspective, the information or disclosure on zakat is perceived as crucial to be disclosed by the Islamic banks. However, some or specifically $25 \%$ of the Islamic banks examined in this study do not disclose information regarding zakat in their 2010 financial reports. In other words, there are several Islamic banks are remained silent on their zakat obligations status.

The issue of zakat should not be an alien to the IFIs including the Islamic banks. This is due to the fact that many IFIs are involved in zakat activities either via the zakat funds administration or through paying a portion or percentage of their profits earned for charitable programmes and activities (Aribi \& Gao, 2012). Besides, according to Maali et al. (2006), the information or disclosure on zakat should not be omitted from the annual reports as it can also provide information to the shareholders and depositors concerning the amount that they should pay for zakat in the event that the Islamic banks are not required to pay zakat. And it is vital to be done by the Islamic banks considering their ethical identity (Haniffa \& Hudaib, 2007.

The other area of concern is with respect to the disclosure of non-allowable earnings among the respective Islamic banks. In this study, it is found that there are a number of Islamic banks that are silent regarding the disclosure of non-allowable earnings or expenditure. In this respect, only $8 \%, 17 \%, 25 \%$ and 33\% of the Islamic Banks made such disclosure in 2007, 2008, 2009 and 2010, respectively. Although the figures are increasing each year, it is yet to surpass or even reach half of the number of Islamic Banks examined.

As asserted by Haniffa (2002), the notion of halal and haram is among the concepts that are well rooted in the Islamic financial and investment activities. The Islamic banks should therefore provide disclosure informing and/or explaining the status of their earnings or expenditures since these issues - halal and haram - are highly sensitive in Islam. In this context, there should be a disclosure made by the Islamic banks to inform the stakeholders even though they have not involved in any haram activities and all of the earnings are halal.

Moreover, by providing the information to the stakeholders, it shows that the Islamic banks are being more transparent about their programmes and activities carried out throughout the year. Such information also reflects that the Islamic banks are being more accountable to their respected users of information. This kind of information is also perceived as able to boost more fruitful relationship with all their stakeholders in the future. 


\subsection{Auditing and Governance}

For the auditing and governance part, the issue of IAH's rights to monitor the investment performance needs to be addressed since no effort is presently being made by the Islamic Banks to cater for such a requirement. Archer and Karim (2007) stress the importance of protecting the needs of the IAHs as they have the right to know how their money is being used or invested.

This is because unlike the shareholders, the IAHs do not have the rights such as board of directors to keep an eye on the management for them, receive an annual reports and to appoint the external auditors, to participate and vote in annual general meeting and to take part in appointing the Shari'ah Supervisory Board (Archer \& Karim, 2007). As of currently, the only avenue for the IAHs to save their money when they feel unsecured about the bank management approach is through funds withdrawals.

Therefore, the Islamic banks should disclose the related policies and practices regarding the investment accounts offered to ensure that the investment accounts holders are able to monitor their investment performance. In this context, through such disclosure, it is viewed that the IAHs rights with respect to the investment accounts can also be met or protected.

\subsection{Social}

For the social part, although the figures increased to $24 \%$ in 2010, much more needs to be done by the Islamic banks as a few do not disclose any of the requirements stated by the regulatory bodies. There should be at least an effort made by the Islamic banks to be involved in basic areas, such as employees' education and training or human capital development, charities, and social activities or donations as necessary to the society.

This involvement is a sort of contribution by the Islamic banks to the society in order to enhance and improve their quality of life. It can also at least help the poor to obtain the basic necessities in life. As noted by Mashhour (1996), Islamic banks are anticipated to prioritise their investments towards solving the problems of society, even though such investments may compromise or affect some of their profits.

In this respect, the information on employees' education and training is considered as essential to be disclosed since it reflects upon the concern of the Islamic banks on the development of their employees in terms of education and training. Further, the information on charities or gifts provides users regarding the concern of the Islamic banks on the society both in Malaysia and abroad. Through this information, the stakeholders at Islamic banks will be notified with respect to the contributions, gifts or charity activities organized by the Islamic banks to the poor or needy nearby or at large.

Moreover, the information on saddaqa or donation is perceived as essential to be disclosed due to the fact that it is highly encouraged in Islam. It will not only assist the needy in improving their quality of life but also reflects that the Islamic banks are on the right track to reduce the economic gaps among people in the society. Nonetheless, a commendable effort has been made by about $25 \%$ of the Islamic banks that have begun their involvement in social reporting in 2007. Their focus should now be extended to involve and provide information for other areas of social reporting while the rest should aim to disclose the basic social disclosure requirements such as human capital development, charities, and social activities. 


\section{CONCLUSION}

The findings on the views of the items in the index of IFSR reflect the importance of the financial part and very close to important for the auditing and governance part. In addition, the practitioners view the social part as fairly important. The result for the social part suggests that the practitioners already acknowledge the existing social reporting elements in the IFSR even though it is not yet viewed as being as important as the financial part. For the findings about the overall weighted score, although the scores have shown an increasing trend from 2007 to 2010 they are only considered as fair. Nevertheless, some individual parts, such as the financial, and the auditing and governance, reflect very good and good disclosure, respectively.

The paper contributes by providing empirical evidence with respect to the disclosures on financial, social and governance among the Islamic banks in Malaysia. Such findings can act as a benchmark for the respected Islamic banks to know their present IFSR disclosure and thereafter can also act as a mechanism to improve their IFSR disclosures. Besides, from the perspective of stakeholders, the finding on financial disclosure provide a positive indication on the status of the Malaysian Islamic banks with respect to the compliance with mandatory reporting requirements which is very important to improve the financial performance of Islamic banks in the future as well.

The finding on social informs the users or stakeholders on the current level of social contribution of the Islamic banks. Such finding can also be used by the Islamic banks to involve in more social activities that can provide more benefits to the society in line with the aspirations of the Islamic banks themselves. From the point of view of auditing and governance disclosure, the stakeholders are informed with regard to the level of auditing and governance activities that currently take place at the Islamic banks. This information is essential as it also reflects on the level of accountability of the Islamic banks towards achieving the objectives of the stakeholders through better use and safeguard of resources at Islamic banks.

To conclude, the social disclosure practices needs more attention from the respective Islamic banks and the relevant regulators in order to gradually improve the social disclosures among Malaysian Islamic banks. For the first phase, considering the still new industry, the respected regulators may attempt to make it mandatory for the Islamic banks to disclose the basic requirements only such as employees' education and training or human capital development, charities, and social activities or donations seeing their important impact to the society. Thereafter, the regulators can act accordingly based on the response and progress in the industry.

\section{LIMITATIONS AND SUGGESTIONS FOR FUTURE STUDIES}

The findings with respect to the level of weighted IFSR disclosure may not be generalised to the years prior and after the examination period. The paper suggests future studies to examine the disclosure of IFSR among the Malaysian Islamic banks in the later period such as 2011 onwards in order to see if there are any differences in terms of disclosures. The study also proposes future studies to use interviews in seeking the views of the practitioners on the importance of items in the IFSR index. And, the paper suggests future studies to develop the rating of score for the respective Islamic banks in Malaysia so that the score can bring more meaning as compared to merely reporting the percentage or score per se. 


\section{REFERENCES}

AAOIFI. (2002). Governance Standard for Islamic Financial Institutions No. 1-4. Accounting and Auditing Standards for Islamic Financial Institutions. Manama, Bahrain: AAOIFI.

Abatecola, G. (2012). Organizational Adaptation: An Update. International Journal of Organizational Analysis, 20(3), 274-293.

Ahmed, H. (2011). Maqasid Al-Shari'ah and Islamic Financial Products: A Framework for Assessment. ISRA International Journal of Finance, 3(1), 149-160.

Alexakis, C., \& Tsikouras, A. (2009). Islamic Finance: Regulatory Framework-Challenges Lying Ahead. International Journal of Islamic and Middle Eastern Finance and Management, 2(2), 90-104.

An-Nabhani, T. (1997). The Economic System in Islam. London: Al-Quilafa Publication.

Archer, S., \& Karim, R. A. A. (2007). Specific Governance Issues in Islamic Banks. In S. Archer \& R. A. A. Karim (Eds.), Islamic Finance: The Regulatory Challenge (pp. 310-341). Singapore: John Wiley \& Sons (Asia) Pte Ltd.

Aribi, Z. A., \& Gao, S. S. (2010). Corporate Social Responsibility Disclosure: A Comparison between Islam and Conventional Financial Institutions. Journal of Financial Reporting and Accounting, $8(2), 72-91$.

Aribi, Z. A., \& Gao, S. S. (2012). Narrative Disclosure of Corporate Social Responsibility in Islamic Financial Institutions. Managerial Auditing Journal, 27(2), 199-222.

Bank Negara Malaysia (BNM). (2005). Guidelines on Financial Reporting for Licensed Islamic Banks (GP8 - i). Malaysia: Bank Negara Malaysia.

Bank Negara Malaysia. (BNM). (2017). List of Licensed Banking Institutions in Malaysia - Islamic Banks. Malaysia: Bank Negara Malaysia.

Baydoun, N., \& Willett, R. (2000). Islamic Corporate Reports. ABACUS, 36(1), 71-90.

Bayoud N. S., Kavanagh M., \& Slaughter G. (2012). Factors Influencing Levels of Corporate Social Responsibility Disclosure by Libyan Firms: A Mixed Study. International Journal of Economics and Finance, 4(4), 13-29.

Branco, M. C., \& Rodrigues, L. L. (2008). Factors Influencing Social Responsibility Disclosure by Portuguese companies. Journal of Business Ethics, 83(4), 685-701.

Cormier, D., \& Gordon, I. (2001). An Examination of Social and Environmental Reporting Strategies. Accounting, Auditing and Accountability Journal, 14(5), 587-616.

Deegan, C. (2002). The Legitimising Effect of Social and Environmental Disclosures- A Theoretical Foundation. Accounting, Auditing and Accountability Journal, 15(3), 282-311.

Deegan, C. (2013). Financial Accounting Theory (4 ${ }^{\text {th }}$ edition). Sydney: McGraw Hill Book Company.

Deegan, C., \& Unerman, J. (2011). Financial Accounting Theory. Sydney: McGraw-Hill.

Dowling, J., \& Pfeffer, J. (1975). Organisational Legitimacy: Social Values and Organizational Behavior. Pacific Sociological Review, 18(1). 122-136.

Farook, S., Hassan, M. K., \& Lanis, R. (2011). Determinants of Corporate Social Responsibility Disclosure: The case of Islamic banks. Journal of Islamic Accounting and Business Research, 2(2), 114-141.

Freeman, R. E. (1984). Strategic Management: A Stakeholder approach. Boston: Pitman.

Graves, S.P., Waddock, S., \& Kelly, M. (2001). How Do You Measure Corporate Citizenship? Business Ethics, 12(2), 155-187.

Gray, R., Owen, D., \& Adams, C. (1996). Accounting and Accountability: Changes and Challenges in corporate social and environmental reporting. Prentice Hall: London.

Haniffa, R. (2002). Social Reporting Disclosure: An Islamic Perspective. Indonesian Management and Accounting Research, 1(2), 128-146. 
Haniffa, R. M., \& Hudaib, M. (2007). Exploring the Ethical Identity of Islamic Banks via Communications in Annual Reports. Journal of Business Ethics, 76(1), 97-116.

Hassan, A., \& Harahap, S. S. (2010). Exploring Corporate Social Responsibility Disclosure: The Case of Islamic Banks. International Journal of Islamic and Middle Eastern Finance and Management, 3(3), 203-227.

Islamic Financial Services Board (IFSB). (2006). Guiding Principles on Corporate Governance for Institutions Offering Only Islamic Financial Services (Excluding Islamic Insurance (Takaful) Institutions and Islamic Mutual Funds). Kuala Lumpur: IFSB.

Khan, M. M., \& Bhatti, M. I. (2008). Islamic Banking and Finance: on Its Way to Globalization. Managerial Finance, 34(10), 708-725.

Lewis, M. K. (2006). Accountability and Islam. Paper Presented at The Fourth International Conference on Accounting and Finance in Transition, Adelaide.

Lightstone, K., \& Driscoll, C. (2008). Disclosing elements of disclosure: a test of legitimacy theory and company ethics. Canadian Journal of Administrative Sciences, 25(1), 7-21.

Maali, B., Casson, P., \& Napier, C. (2006). Social Reporting by Islamic Banks. ABACUS, 42(2), 266-289. Magness, V. (2006). Strategic Posture, Financial Performance and Environmental Disclosure: An Empirical Test of Legitimacy Theory, Accounting, Auditing and Accountability Journal, 19(4), $540-563$.

Malaysian Accounting Standard Board (MASB). (2009). MASB Technical Release i-3. Presentation of Financial Statements of Islamic Financial Institutions. Malaysia: MASB.

Marsidi, A., Annuar, H. A., \& Abdul Rahman, A. R. (2016). The Formulation of Financial, Governance and Social Index of Malaysian Islamic Banks: An Integrative Approach. Risk Governance and Control: Financial Markets and Institutions, 6(1), 64 - 70.

Mashhour, N. (1996). Social and Solidarity Activity in Islamic Banks. US: International Institute of Islamic Thoughts.

Newson, M., \& Deegan, C. (2002). Global Expectations and Their Association with Corporate Social Disclosure Practices in Australia, Singapore, and South Korea. The International Journal of Accounting, 37, 183 - 213.

O’Donovan, G. (2002). Environmental Disclosures in the Annual Report: Extending The Applicability and Predictive Power of Legitimacy Theory. Accounting, Auditing and Accountability Journal, 15(3), 344-371.

Othman, R., \& Md Thani, A. (2010). Islamic Social Reporting of Listed Companies in Malaysia. International Business \& Economics Research Journal, 9(4), 135-144.

Porter, B. A. (2009). The Audit Trinity: The Key to Securing Corporate Accountability. Managerial Auditing Journal, 24(2), 156-182.

Roberts, J. (1991). The Possibilities of Accountability. Accounting, Organisations and Society, 16(4), 355-368.

Roberts, J., \& Scapens, R. (1985). Accounting Systems and Systems of Accountability - Understanding Accounting practices in their organisational contexts. Accounting, Organisations and Society, 10(4), 443-456.

Securities Commission of Malaysia. (2010). Retrieved from http://www.sm.com.my/

Simmons, J. (2004). Managing in the Post-managerialist Era: Towards Socially Responsible Corporate Governance. Management Decision, 42(3/4), 601-611.

Stinchcombe, A. L. (1965). Social Structure and Organization. In J. March (Eds.), Handbook of Organizations (pp. 142-193). Chicago: Rand McNally.

Sulaiman, M., \& Willett, R. (2001). Islam, Economic Rationalism and Accounting. The American Journal of Islamic Social Sciences, 18(2), 61-93.

Tinker, T. (1991). Accountant as Partisans. Accounting, Organizations \& Society, 16(3), 297-311.

Wearing, R. (2005). Cases in Corporate Governance. London. SAGE Publications. 